\title{
Lesch-Nyhan Disease and Its Variants: Phenotypic and Mutation Spectrum of Hypoxanthine-Guanine Phosphoribosyltransferase Deficiency in Argentine Patients
}

Journal of Inborn Errors of Metabolism \& Screening 2021, Volume 9: e20200027 DOI: https://doi.org/10.1590/2326-4594JIEMS-2020-0027

\author{
Laura E. Laróvere ${ }^{1,2}$ (D), Lynette D. Fairbanks ${ }^{3}$, H. A. Jinnah ${ }^{4}$, \\ Norberto B. Guelbert ${ }^{5}$, Emilia Escuredo ${ }^{3}$, Adriana Becerra ${ }^{5}$ \\ and Raquel Dodelson de Kremer ${ }^{1}$
}

\begin{abstract}
Hypoxanthine-guanine phosphoribosyltransferase (HPRT) deficiency is a disorder of purine metabolism responsible for Lesch-Nyhan Disease (LND) and its variants, HPRT-related hyperuricemia with neurologic dysfunction (HND) and HPRT-related hyperuricemia $(\mathrm{HRH})$. The objective of this study was to characterize a cohort of Argentine patients with HPRT deficiency diagnosed in a single center. Results: Twenty nine patients were studied, including 12 LND,15 HND and $2 \mathrm{HRH}$. The average onset age was 0.64 years for LND with motor delay as the main manifestation, 8.84 years for HND and 2.5 years for $\mathrm{HRH}$; nephrological manifestations predominated as presenting features in these variants. The average diagnosis age was 3.58 years for LND, 17.21 years for HND and 2.5 years for $\mathrm{HRH}$. Clinical heterogeneity was more evident in HND, even in members of the same family. All patients presented hyperuricemia and no detectable HPRT activity in erythrocyte lysate. The molecular study allowed to identify 9 different mutations in HPRT1 gene from 24 patients (11 independent pedigrees) and to establish genotype-phenotype correlation. In conclusion, this study describes the genotypic/phenotypic spectrum of HPRT deficiency in Argentine patients and highlights the need to increase awareness about the suspicion of these diseases, especially the LND variants with high clinical heterogeneity.
\end{abstract}

\section{Keywords}

Hypoxanthine-guanine phosphoribosyltransferase deficiency, hyperuricemia, Lesch-Nyhan disease, Lesch-Nyhan variant, HPRT1 mutation.

\section{Introduction}

Hypoxanthine-guanine phosphoribosyltransferase (HPRT; EC 2.4.2.8) deficiency (MIM 308000) is an X-linked genetic defect of the purine salvage pathway whereby purine bases are recycled into nucleotides[1,2]. The HPRT enzyme catalyzes the transfer of the 5-phosphoribosyl group from 5-phosphoribosyl-1pyrophosphate (PRPP) to a purine base hypoxanthine or guanine to form IMP or GMP, respectively. The metabolic consequence of HPRT deficiency is an increase of de novo purines synthesis, which leads to increased production of uric acid, causing a variety of renal and joint symptoms. HPRT deficiency causes also an increased in the concentration of hypoxanthine, which is not reused, and contributes to uric acid increases[2,3].

\footnotetext{
${ }^{1}$ Centro de Estudio de las Metabolopatías Congénitas, Hospital de Niños de la Santísima Trinidad; Clínica Pediátrica, Facultad de Ciencias Médicas, Universidad Nacional de Córdoba, Córdoba, Argentina.

${ }^{2}$ Consejo de Investigaciones Científicas y Tecnológicas, Argentina.

3 Purine Research Laboratory, St Thomas' Hospital, London, UK.

${ }^{4}$ Emory University, Departments of Neurology, Human Genetics and Paediatrics, Atlanta, GA, USA.

${ }^{5}$ Hospital de Niños de la Santísima Trinidad, Sección Enfermedades Metabólicas, Córdoba, Argentina.
}

Received November 30, 2020, and in revised form February 02, 2021. Accepted for publication February 09, 2021.

\section{Corresponding Author:}

Laura Laróvere, Universidad Nacional de Córdoba, Facultad de Ciencias Médicas, Hospital de Niños de la Santísima Trinidad Clínica Pediátrica, Centro de Estudio de las Metabolopatías Congénitas, Córdoba, Argentina.

Email: lauralarovere@hotmail.com; lauraelarovere@gmail.com 
HPRT deficiency involves a large spectrum of neurological and behavioural abnormalities. Depending on the degree of the enzyme deficiency three main clinical phenotypes have been described: fully developed Lesch-Nyhan disease (LND) presenting severe neurologic dysfunction (self-injury, motor disability, gout, and renal problems); the intermediate phenotype designed HPRT-related hyperuricemia with neurologic dysfunction (HND); and HPRT-related hyperuricemia (HRH), associated with marked overproduction of uric acid, with resultant hyperuricemia, nephrolithiasis, and gout[2]. Affected individuals with the classical or variant forms show excessive production of uric acid that increases the risk for renal stones, renal failure, gouty arthritis, and tophi. Since the disease is inherited in an X-linked recessive manner, the most cases are males; however, several manifesting females have been reported[4].

The HPRT enzyme is encoded by a single gene (HPRT1) that has nine exons spanning approximately $45 \mathrm{~kb}$ at Xq26-27[5]. More than 600 different disease-causing gene variants have been reported for the HPRT1 gene (www.lesch-nyhan.org). Spread through nearly the whole gene are missense variants, nonsense variants, splicing variants, small and large coding and non-coding deletions or insertions, partial duplications, non-coding regulatory variants, and more complex changes[4].

The mechanism of neurological and behavioural features of the disease is not clear, although the role of basal ganglia circuits and dopaminergic system have been demonstrated to be impaired[6-8].

Treatment of HPRT deficiency comprises pharmacological therapy of hyperuricemia with administration of allopurinol for renal failure prevention. In addition, the treatment for LNS includes comprehensive medical management, dental management, physical therapy, behavioural, and psychiatric interventions. Behaviour and psychiatry management targets self-injury through the use of restraints, behavioural management, psychopharmacologic management, and deep brain stimulation[9].

There are a few population studies that allow the prevalence of LND to be estimated:[3,10-16] which is approximately $1: 380,000$ [17]. Furthermore, due to the clinical heterogeneity of the patients (especially in the LND variants), the number of affected individuals is not well studied and may be underestimated. Patients with the classical phenotype (LND) rarely survive beyond the third decade; however, lifespan may be normal for Lesch-Nyhan variants without severe renal involvement[9].

The present study describes a cohort of 29 Argentine patients with HPRT deficiency, including both LND and its attenuated variants, diagnosed in a single referral center (CEMECO, Children's Hospital of Córdoba, Argentina).

\section{Patients and Methods}

We performed a retrospective, descriptive and comparative study in a cohort of Argentine patients with HPRT deficiency in CEMECO, Children's Hospital of the Santísima Trinidad de Córdoba, between 1996-2020. Informed consent was obtained from parents and, when possible, from patients.

This study included 29 Argentine male patients from 15 unrelated families who were diagnosed between 1996-2020. HPRT deficiency in probands was diagnosed on the basis of: a) suggestive clinical symptoms and signs; b) laboratory findings indicative of purine overproduction (serum uric acid levels and urine oxypurines; c) markedly reduced HPRT activity in haemolysates with simultaneously increased of adenine phosphoribosyltransferase (APRT) activity; and d) confirmed by HPRT1 gene mutation.

The patients were classified according to previously established subgroups: LND, HND and HRD and based on the presence or absence of different signs/symptoms[2]. Some cases have been described in previous studies (detailed in Results and Discussion). The data were obtained retrospectively from medical records of consultations with paediatric specialists in hereditary metabolic diseases or by referring physicians.

Blood and urine samples were collected from patients with clinical suspicion of HPRT deficiency to perform a metabolite study, enzyme activity and investigation of the genetic defect. The determination of purine metabolites (urine) and HPRT enzymatic assay (erythrocyte lysates) were performed by HPLC methods according to Simmonds et al, 1991[18]. The molecular analysis of the HPRT gene mutations included amplification of the entire coding region of the HPRT mRNA by rt-PCR[19] and genomic multiplex PCR, followed by direct sequencing of PCR products[20,21].

The $t$-test for independent samples from the Infostat program was used for comparison of onset age and diagnosis age between the groups.

\section{Results and Discussion}

This study represents the serial recognition of HPRT deficiency with classical phenotype of LND and its variants in Argentina. A total of 29 male patients from 15 unrelated families were identified. Demographic data is showed in Table 1. The phenotypic distribution was $41.4 \%$ (12/29) patients with LND, $51.7 \%(15 / 29)$ with HND the intermediate phenotype, and $6.9 \%$ (2/29) with HRH variant. The phenotypic distribution in this study is influenced by several members coming from the same family. There is the possibility that a large family with 10 patients results in bias of distribution. 
Disease onset, age at diagnosis and first/main manifestations

The average age of onset of symptoms (Table 1 ) was 0.64 years (range 0.33-1 year) for LND patients, whose main manifestation was motor delay, while the onset of self-injury was present in $100 \%$ of the cases at the average age of 4.22 years (range $2-8$ years), the most frequent self-injurious behaviours were biting fingers, tongue or lips. Other early symptoms present in the LND patients were the appearance in 9/12 cases of involuntary movements (dystonia and other abnormal movements) and abnormalities resembling cerebral palsy in 5/12. LND patients who had nephrological manifestations such as kidney stones and uric acid crystals were those diagnosed after three years of age. The degree of cognitive impairment was not evaluated in this group of patients.

In patients classified as variants (LNV), the age of onset of symptoms was 8.84 years (range 0.1-28 years) for HND and 2.5 years (range 1-4 years) for HRH. Nephrological manifestations predominated as presenting symptoms in 60\% (9/15) and 100\% (2/2) in HND and HRH, respectively; followed by joint disease $33 \%(5 / 15)$ and motor retardation $26.7 \%(4 / 15)$ in HND and without these types of manifestations in HRH. Regarding the clinical outcome and the appearance of new symptoms, $93.3 \%$ (14/15) HND patients presented different degrees of cognitive impairment (even in the same family), one patient was a newborn without data about cognitive abnormalities; 66.6\% (10/15) HND and 50\% (1/2) HRH had nephrological manifestations; joint disease was present in $66.6 \%(10 / 15)$ cases HND, all older than 13 years and with a delay in diagnosis. Comparing the groups of patients, there was a significant difference $(\mathrm{p}<0.005)$ in the age of onset between LND and HND.

The average age of diagnosis in the groups was 3.58 years (range 0.5-10 years) for LND, 17.21 years (range 0.1-56 years) for
HND and 2.5 years (range 1-4 years) for HRH. The diagnostic delay was significantly lower in LND than patients affected by HND ( $\mathrm{p}<0.005$ ), according to previous reports; $[3,23]$ this could be because the diagnosis of the classic form is more oriented due to self-injury symptoms.

Regarding family 13 , it should be noted that these cases $(n=10)$ have a different degree of kinship relationship with a common ancestor 5 generations ago (Figure 1). Some of them came to our center for consultation due to the appearance of different symptoms (Table 1) and only 2 did so prior to the appearance of clinical manifestations due to family history regarding the disease. The clinical heterogeneity observed in those affected in the family is very high, although all are classified as HND; the outcome and complications were strongly related to the age of diagnosis. The broad spectrum of clinical features in HND variant reported by Jinnah et al (2010)[22] indicates, in addition to the overproduction of uric acid, different degrees of varying degrees of motor, cognitive, or behavioural abnormalities.

\section{Metabolites, enzymatic activity and genotype}

All patients had hyperuricemia (Table 1) with a mean value of $11.86 \mathrm{mg} / \mathrm{dl}$ (range 7.7-17); the urine purine study performed in $21 / 29$ patients (pooled data) showed an increase of uric acid (range 1400-2300 $\mu \mathrm{mol} / \mathrm{mmol}$ creatinine; normal values $>1300$ ), hypoxanthine (range $55-778 \mu \mathrm{mol} / \mathrm{mmol}$ creatinine; normal values $>45$ ) and xanthine (range $23-200 \mu \mathrm{mol} / \mathrm{mmol}$ creatinine; normal values $>43)$; these metabolites are indicative of HPRT deficiency[18].

The HPRT enzyme assay in erythrocyte lysate was performed in all the entire cohort of patients, with no activity detected in any of these cases (Table 1); these results were not correlated with the different phenotypes in which the patients were grouped. These differences could be observed using tests on intact red

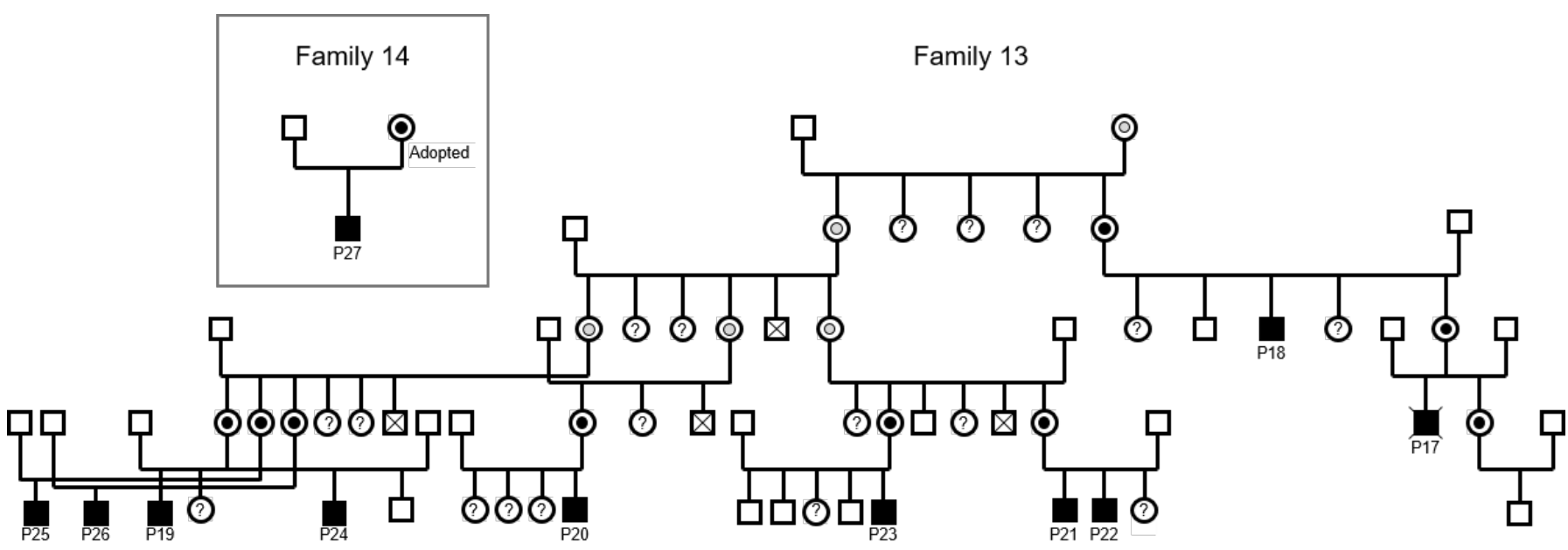

Figure 1. Genealogy of families 13 and 14 with HPRT deficiency, carriers of same HPRT1 mutation: c.584A>C (p.Y195S).

, affected male; $\square$, unaffected male; $\boldsymbol{O}$, carrier female; $\boldsymbol{O}$, obligate carrier female; ?, status unknown; $X$, deceased subject. The code names are shown for the patients analysed in this study. 
Table 1. HPRT deficiency in Argentine patients: age of onset / diagnosis, uric acid in blood, enzymatic activity, main features and treatment.

\begin{tabular}{|c|c|c|c|c|c|c|c|c|c|}
\hline Case & Family & $\begin{array}{c}\text { Age } \\
\text { (diagnosis) }\end{array}$ & $\begin{array}{l}\text { Blood UA } 1 \\
\text { (diagnosis) }\end{array}$ & $\begin{array}{c}\text { HPRT } \\
\text { Activity }^{2}\end{array}$ & $\begin{array}{l}\text { Self-injury } \\
\text { (onset) }\end{array}$ & Neurological dysfunction & $\begin{array}{l}\text { Nephrological } \\
\text { manifestations }\end{array}$ & Joint disease & Treatment \\
\hline \multicolumn{10}{|c|}{ Lesch-Nyhan disease } \\
\hline 1 & 1 & 5 years & $11.0 \mathrm{mg} / \mathrm{dl}$ & $<1$ & $\begin{array}{c}x \\
(5 \text { years })\end{array}$ & $\begin{array}{l}\text { Motor delay (6 months) } \\
\text { Dystonia superimposed on hypotonia }\end{array}$ & Recurrent renal stones & - & $\begin{array}{l}\text { Allopurinol } \\
\text { Risperidone } \\
\text { Folate } \\
\text { SAM }\end{array}$ \\
\hline 2 & 2 & 10 years & $8.1 \mathrm{mg} / \mathrm{dl}$ & $<1$ & $\begin{array}{c}x \\
\text { (6 years) }\end{array}$ & $\begin{array}{c}\text { Motor delay (8 months) } \\
\text { Dystonic and ballismic } \\
\text { movements at } 1 \text { year } \\
\text { Epilepsy }\end{array}$ & Recurrent renal stones & - & $\begin{array}{c}\text { Allopurinol } \\
\text { Carbamazepine } \\
\text { Clonazepam Folate }\end{array}$ \\
\hline 3 & 3 & 9 years & $9.2 \mathrm{mg} / \mathrm{dl}$ & $<1$ & $\begin{array}{c}x \\
\text { (8 years) }\end{array}$ & $\begin{array}{c}\text { Motor delay (8 months) } \\
\text { Dystonia } \\
\text { Generalized hypotonia } \\
\text { with hyperreflexia }\end{array}$ & Uric acid crystals & - & $\begin{array}{l}\text { Allopurinol } \\
\text { Clonazepam }\end{array}$ \\
\hline 4 & 4 & 11 months & $9.8 \mathrm{mg} / \mathrm{dl}$ & $<1$ & - & $\begin{array}{c}\text { Spastic quadriplegia (10 months) } \\
\text { Dystonia } \\
\text { Axial hypotonia }\end{array}$ & - & - & Allopurinol \\
\hline 5 & 5 & 4 years & $7.7 \mathrm{mg} / \mathrm{dl}$ & $<1$ & $\begin{array}{c}x \\
\text { (8 years) }\end{array}$ & $\begin{array}{c}\text { Motor delay (4 months) } \\
\text { Dystonia } \\
\text { Choreoathetosis }\end{array}$ & Kidney stones & - & $\begin{array}{l}\text { Allopurinol } \\
\text { Risperidone }\end{array}$ \\
\hline 6 & 5 & 3 years & $8.2 \mathrm{mg} / \mathrm{dl}$ & $<1$ & $\begin{array}{c}x \\
(3 \text { years })\end{array}$ & $\begin{array}{c}\text { Motor delay (7 months) } \\
\text { Dystonia } \\
\text { Choreoathetosis } \\
\text { Generalized hypotonia } \\
\text { with hyperreflexia }\end{array}$ & Kidney stones & - & $\begin{array}{l}\text { Allopurinol } \\
\text { Clonazepam }\end{array}$ \\
\hline 7 & 6 & nd & nd & $<1$ & $x$ & $\begin{array}{l}\text { Motor delay } \\
\text { Dystonia } \\
\text { Choreoathetosis }\end{array}$ & $\mathrm{Nd}$ & nd & nd \\
\hline 8 & 7 & 1 year & $8.0 \mathrm{mg} / \mathrm{dl}$ & $<1$ & $x$ & Dystonic cerebral palsy & - & - & nd \\
\hline 9 & 8 & 2 years & $12.5 \mathrm{mg} / \mathrm{dl}$ & $<1$ & $\begin{array}{c}x \\
(2 \text { years })\end{array}$ & $\begin{array}{c}\text { Motor delay (5 months) } \\
\text { Spastic-dystonic tetraparesis } \\
\text { Microcephaly }\end{array}$ & - & - & nd \\
\hline 10 & 9 & 2 years & nd & $<1$ & $x(2$ years $)$ & Spastic quadriplegia & - & - & nd \\
\hline 11 & 9 & 2 years & nd & $<1$ & $x(2$ years $)$ & Spastic quadriplegia & - & - & nd \\
\hline 12 & 10 & 6 months & $8 \mathrm{mg} / \mathrm{dl}$ & $<1$ & - & Motor delay (5 months) & - & - & nd \\
\hline
\end{tabular}


Table 1. Cont

\begin{tabular}{|c|c|c|c|c|c|c|c|c|c|}
\hline Case & Family & $\begin{array}{c}\text { Age } \\
\text { (diagnosis) }\end{array}$ & $\begin{array}{l}\text { Blood UA }{ }^{1} \\
\text { (diagnosis) }\end{array}$ & $\begin{array}{c}\text { HPRT } \\
\text { Activity }^{2}\end{array}$ & $\begin{array}{l}\text { Self-injury } \\
\text { (onset) }\end{array}$ & Neurological dysfunction & $\begin{array}{c}\text { Nephrological } \\
\text { manifestations }\end{array}$ & Joint disease & Treatment \\
\hline \multicolumn{10}{|c|}{ HPRT-related hyperuricemia with neurologic dysfunction } \\
\hline 13 & 11 & 9 years & $9.0 \mathrm{mg} / \mathrm{dl}$ & $<1$ & - & $\begin{array}{c}\text { Motor delay (<1 year) } \\
\text { Slightly slow gait } \\
\text { Speech delay, slightly slow } \\
\text { and indistinct } \\
\text { Hypomimia } \\
\text { Brisk leg reflexes, ankle clonus } \\
\text { Significant cognitive impairment }\end{array}$ & - & - & Allopurinol \\
\hline 14 & 11 & 56 years & $\begin{array}{c}\text { with } \\
\text { allopurinol } \\
\text { treatment }\end{array}$ & $<1$ & - & $\begin{array}{c}\text { Moderate dystonic dysarthria } \\
\text { Slightly slow gait } \\
\text { Brisk leg reflexes, } \\
\text { peripheral neuropathy } \\
\text { Mild cognitive impairment }\end{array}$ & $\begin{array}{l}\text { Nephrolitiasis } \\
\text { Renal insufficiency }\end{array}$ & $\begin{array}{l}\text { Tophus on } \\
\text { knee (28 } \\
\text { years) }\end{array}$ & $\begin{array}{l}\text { Allopurinol } \\
\text { Glibencamide }\end{array}$ \\
\hline 15 & 11 & 37 years & $\begin{array}{l}\text { with } \\
\text { allopurinol } \\
\text { treatment }\end{array}$ & $<1$ & - & $\begin{array}{c}\text { Motor delay (1.5 year) } \\
\text { Slightly slow gait } \\
\text { Moderate dystonic dysarthria } \\
\text { Slow/clumsy hand movements; } \\
\text { brisk arm and leg reflexes, neuropathy } \\
\text { Mild cognitive impairment }\end{array}$ & $\begin{array}{c}\text { Gout } \\
\text { Nephrolithiasis }\end{array}$ & $\begin{array}{l}\text { Recurrent tophi } \\
\text { Joint } \\
\text { deformities of } \\
\text { the hands and } \\
\text { feet }\end{array}$ & Allopurinol \\
\hline 16 & 12 & 20 years & $11.5 \mathrm{mg} / \mathrm{dl}$ & $<1$ & - & $\begin{array}{l}\text { Psychomotor development } \\
\text { retardation (<1 year) } \\
\text { Slightly indistinct speech } \\
\text { Normal gait but can't edge-walking } \\
\text { Slow/clumsy hand movements } \\
\text { Brisk arm and leg reflexes, ankle clonus } \\
\text { Severe cognitive impairment }\end{array}$ & Bilateral renal lithiasis & $\begin{array}{l}\text { Asymmetric } \\
\text { polyarthritis } \\
\text { of hands, both } \\
\text { knees, ankles } \\
\text { and feet }\end{array}$ & Allopurinol \\
\hline 17 & 13 & 14 years & $16.0 \mathrm{mg} / \mathrm{dl}$ & $<1$ & - & $\begin{array}{c}\text { Motor delay (2 years) } \\
\text { Hypophonic speech } \\
\text { Normal gait } \\
\text { Slightly slowed hand movements } \\
\text { Marked cognitive impairment }\end{array}$ & $\begin{array}{l}\text { Renal insufficiency } \\
\text { Nephrolitiasis }\end{array}$ & $\begin{array}{l}\text { Tophi } \\
\text { Joint } \\
\text { deformities of } \\
\text { the hands, feet, } \\
\text { elbows }\end{array}$ & $\begin{array}{l}\text { Allopurinol } \\
\text { Enapril }\end{array}$ \\
\hline 18 & 13 & 19 years & $14.6 \mathrm{mg} / \mathrm{dl}$ & $<1$ & - & $\begin{array}{l}\text { Normal speech and gait } \\
\text { Minor overflow posturing of one hand } \\
\text { Mild cognitive impairment }\end{array}$ & Gout (19 years) & Tophi & Allopurinol \\
\hline 19 & 13 & 15 years & $13.8 \mathrm{mg} / \mathrm{dl}$ & $<1$ & - & $\begin{array}{l}\text { Mild cognitive impairment } \\
\text { Speech and gait: nd }\end{array}$ & $\begin{array}{l}\text { Renal insufficiency } \\
\text { Nephrolitiasis }\end{array}$ & $\begin{array}{l}\text { Uric acid } \\
\text { crystal in } \\
\text { finger (14 } \\
\text { years) } \\
\text { Tophi }\end{array}$ & Allopurinol \\
\hline 20 & 13 & 13 years & $9.6 \mathrm{mg} / \mathrm{dl}$ & $<1$ & - & $\begin{array}{l}\text { Moderate cognitive impairment } \\
\text { Speech and gait: nd }\end{array}$ & - & Tophi & Allopurinol \\
\hline
\end{tabular}


Table 1. Cont.

\begin{tabular}{|c|c|c|c|c|c|c|c|c|c|}
\hline Case & Family & $\begin{array}{c}\text { Age } \\
\text { (diagnosis) }\end{array}$ & $\begin{array}{l}\text { Blood UA }{ }^{1} \\
\text { (diagnosis) }\end{array}$ & $\begin{array}{c}\text { HPRT } \\
\text { Activity }^{2}\end{array}$ & $\begin{array}{l}\text { Self-injury } \\
\text { (onset) }\end{array}$ & Neurological dysfunction & $\begin{array}{l}\text { Nephrological } \\
\text { manifestations }\end{array}$ & Joint disease & Treatment \\
\hline 21 & 13 & 3 years & $14.4 \mathrm{mg} / \mathrm{dl}$ & $<1$ & - & $\begin{array}{l}\text { Mild cognitive impairment } \\
\text { Speech and gait: nd }\end{array}$ & $\begin{array}{l}\text { Recurrent urinary } \\
\text { infections ( } 3 \\
\text { months) } \\
\text { Nephrocalcinosis } \\
\text { (10 months) }\end{array}$ & - & $\begin{array}{c}\text { Allopurinol } \\
\text { Iron supplement } \\
\text { Folic acid } \\
\text { Sodium bicarbonate }\end{array}$ \\
\hline 22 & 13 & 2 months ${ }^{3}$ & $8.5 \mathrm{mg} / \mathrm{dl}$ & $<1$ & - & $\begin{array}{l}\text { Mild cognitive impairment } \\
\text { Speech and gait: nd }\end{array}$ & - & - & Allopurinol \\
\hline 23 & 13 & 7 days $^{3}$ & $17.0 \mathrm{mg} / \mathrm{dl}$ & $<1$ & - & nd & - & - & Allopurinol \\
\hline 24 & 13 & 21 years & $19.0 \mathrm{mg} / \mathrm{dl}$ & $<1$ & - & $\begin{array}{l}\text { Moderate mental retardation } \\
\text { Speech and gait: nd }\end{array}$ & $\begin{array}{c}\text { Polycystic kidney } \\
\text { disease (1 year) } \\
\text { Chronic renal failure } \\
\text { Kidney transplant }\end{array}$ & Tophi & Allopurinol \\
\hline 25 & 13 & 20 years & $13.0 \mathrm{mg} / \mathrm{dl}$ & $<1$ & - & $\begin{array}{l}\text { Moderate mental retardation } \\
\text { Speech and gait: nd }\end{array}$ & Kidney stones & $\begin{array}{l}\text { Inflammation } \\
\text { of the toe }\end{array}$ & $\begin{array}{l}\text { Allopurinol } \\
\text { Colchicine }\end{array}$ \\
\hline 26 & 13 & 24 years & $14.0 \mathrm{mg} / \mathrm{dl}$ & $<1$ & - & $\begin{array}{l}\text { Moderate mental retardation } \\
\text { Speech and gait: nd }\end{array}$ & nd & $\begin{array}{c}\text { Tophus on } \\
\text { ear } \\
\text { Knee } \\
\text { inflammation }\end{array}$ & Colchicine \\
\hline 27 & 14 & 9 years & $17.3 \mathrm{mg} / \mathrm{dl}$ & $<1$ & - & $\begin{array}{l}\text { Mild cognitive impairment } \\
\text { Speech and gait: nd }\end{array}$ & $\begin{array}{l}\text { Acute renal failure } \\
\text { ( } 9 \text { years) }\end{array}$ & - & Allopurinol \\
\hline \multicolumn{10}{|c|}{ HPRT-related hyperuricemia } \\
\hline 28 & 15 & 4 years & $15.6 \mathrm{mg} / \mathrm{dl}$ & $<1$ & - & - & $\begin{array}{c}\text { Acute renal failure } \\
\text { (4 years) }\end{array}$ & - & Allopurinol \\
\hline 29 & 15 & 1 year $^{3}$ & $9.0 \mathrm{mg} / \mathrm{dl}$ & $<1$ & - & - & - & - & Allopurinol \\
\hline
\end{tabular}

'Blood uric acid, normal range 3.4-7 mg/d; ${ }^{2} \mathrm{HPRT}$ activity in erythrocyte lysate, normal range $80-130 \mathrm{nmol} / \mathrm{h} / \mathrm{mg} \mathrm{Hb}$; ${ }^{3}$ Diagnosis prior to the appearance of clinical manifestations due to family history. In bold letters, the presenting problem and age of onset; nd, no data. Neurological features, in special speech, gait and other motor abnormalities were evaluated in six HND patients. 
blood cells that detect a significant residual activity due to the fact that the cell structure remains intact, which does not occur in lysed cells[2,3]. Parallel to the HPRT activity, APRT enzyme assay was also performed, which was found to be elevated in all the cases (data not shown) as a compensatory mechanism in the increased purine nucleotide synthesis via the salvage pathway and increased availability of PRPP[24].

Nine different genetic variants in $H P R T 1$ gene were identified from 24 patients with 11 independent pedigrees, all these changes were descripted previously (Table 2). Molecular analyses of 5 patients have not been performed. Variants were distributed throughout the gene, and included missense variants $(44.4 \%$, $4 / 9)$, splice site variants $(33.3 \%, 3 / 9)$, a large deletion (11.1\%, $1 / 9)$, and a duplication $(11.1 \%, 1 / 9)$.

The molecular study was carried out on patients, their mothers and other female relatives (data not shown); molecular diagnosis in HPRT-deficient patients allows characterize the genetic variants and perform the detection of carrier women. Only patient 2 had a de novo variant (c.209G>A, G70E), that has been reported in several cases; therefore, this variant qualifies as a hotspot and is clearly a de novo germinal event[25]. It should be noted that patient 16 (family 12) had the same variant (c.143G $>$ A p.R48H) as that identified in family 11 with a similar phenotype[25,26], without knowing any relationship between them; and the case 27 (family 14) had the same variant (c.584A>C, p.Y195S) as members of family 13 (Figure 1), no relationship could be established since the genealogical data of family 14 are not known.

In this family, with a large number of identified cases and the same genetic variant, there is great clinical heterogeneity as shown in Table 1. Yamada et al (2014) also reported phenotypic variability in 3 cases of affected siblings with the same HPRT1 mutation[28].

A comparison of local genetic variants findings with a review article by Fu and colleagues[4] and the web site http://leschnyhan.org/en/research/mutations-database, reveals that the majority of recurrent variants produced a similar phenotype even in unrelated patients. However, there were a few exceptions where the same variant caused discordant phenotypes. Respect to our data, the missense mutation c.143G $>\mathrm{A}$ has 12 reports associated with LNV, HND and HRH; c.209G>A with 8 reports in LND; and c.584A>C has only been described in our series of HND patients and it is the most frequent variant in our report $(11 / 29)$. The only variant with discordant clinical phenotype was c.203T>C, described in 2 LND and 1 HND. The splicing variant c. $485+5 \mathrm{G}>\mathrm{A}$ was reported twice in $\mathrm{LNV}, \mathrm{c} .532+1 \mathrm{G}>\mathrm{A}$ with 4 reports in LND and c.609+6T $>\mathrm{G}$ described in 2 reports of LND. The splicing variants that result in exon exclusions are mostly associated with LND, however c.485+5G $>$ A with exon 6 exclusion showed a mild phenotype. The exons $4-6$ deletion with 3 reports was associated like all large deletions with a severe phenotype (LND). The 212dupG duplication was considered a hot spot for variants, it has arisen multiple times in unrelated patients $(n=15)$ with LND; this variant produces a frame shift and premature stop.

Another analysis is focused on the missense variants and their location in the HPRT1 gene, in which conserved regions associated with the active site of the enzyme were recognized[4]; the four variants identified in our patients occurred in 3 of the 5 recognized "hot clusters". Furthermore, the c.203T > C (p.L68P) and c.209G>A (p.G70E) mutations identified in patients with LND are located in highly conserved amino acids of the HGprt protein with importance for the active site[4].

\section{Treatment and other remarks}

Although this work is not focused on the treatment and outcomes of patients, it is important to remark that allopurinol is widely used to treat renal and joint disease, this medication is also used by our patients for this purpose (Table 1). The management or treatment of neurological involvement and behavioural abnormalities varies. However, some therapies were associated to an improvement of at least some manifestations of the disease. The therapies include benzodiazepines, anxiolytics/hypnotics, antidepressants, antipsychotics and muscle relaxants[3]. One of the cohort used S-adenosylmethionine without showing noticeable changes in mood and behaviour improvement. There are no data on the evolution of most of the patients, according to records of those who are followed up in our hospital, 3 have died (2 LND, $1 \mathrm{HND}$ ), $2 \mathrm{HND}$ are on dialysis and 1 was HND had a kidney transplant.

\section{Conclusions}

This report describes the main clinical features, and biochemical and molecular genetic findings in a cohort of 29 Argentine patients with HPRT deficiency diagnosed in a single center. According to the clinical presentation the patients were classified as LND, HND and HRH. The result of HPRT enzyme activity in erythrocyte lysates could not be correlated with the different phenotypes. However, the identification of mutations allowed genotype-phenotype correlation in most patients and the detection of carrier women.

The main limitation of this study was the data collection method; the clinical characteristics of the patient series were retrospectively analysed with missing data in some cases and based on evaluations made by different physicians. The clinical data are of great importance for the classification and its follow-up, it is necessary to carry out a complete clinical evaluation including renal and joint manifestations, neurological dysfunction and behavioural disorders.

It is important to raise awareness about this disease in the classic form of LND and its variants. Males with developmental delay, neurological and behavioural problems, and hyperuricemia could be affected by HPRT deficiency with severe phenotype; the association of juvenile gout, hyperuricemia and elevated urinary uric acid excretion with or without neurological 
Table 2. HPRT1 gene mutations with corresponding protein level alterations/consequences, phenotypic classification of the 24 patients whose genotypic characterization was available and previous descriptions.

\begin{tabular}{|c|c|c|c|c|c|c|}
\hline Case & Family & Phenotype & Mutation & Result & Remark & Prior reports \\
\hline 13 & 11 & HND & c. $143 \mathrm{G}>\mathrm{A}$ & p.R48H & & $\begin{array}{l}\text { Laróvere et al., } 2007 \text { [25] } \\
\text { Jinnah et al., } 2010 \text { [22] }\end{array}$ \\
\hline 14 & 11 & HND & c. $143 \mathrm{G}>\mathrm{A}$ & p.R48H & & Laróvere et al., 2007 [25] \\
\hline 15 & 11 & HND & c. $143 \mathrm{G}>\mathrm{A}$ & p.R48H & & Laróvere et al., 2007 [25] \\
\hline 16 & 12 & HND & c. $143 \mathrm{G}>\mathrm{A}$ & p.R48H & & Sapag et al., 2012 [26] \\
\hline 1 & 1 & LND & c. $203 T>C$ & p.L68P & & $\begin{array}{l}\text { Jinnah et al., } 2006 \text { [27] } \\
\text { Laróvere el al., } 2007 \text { [25] }\end{array}$ \\
\hline 2 & 2 & LND & c. $209 \mathrm{G}>\mathrm{A}$ & p.G70E & de novo & $\begin{array}{l}\text { Jinnah et al., } 2006 \text { [27] } \\
\text { Laróvere et al., } 2007 \text { [25] }\end{array}$ \\
\hline 3 & 3 & LND & 212dupG & Frame shift in E3 & & Fu et al., 2014 [4] \\
\hline 28 & 15 & $\mathrm{HRH}$ & c. $485+5 G>A$ & Exon 6 excluded & & Fu et al., 2014 [4] \\
\hline 29 & 15 & $\mathrm{HRH}$ & c. $485+5 G>A$ & Exon 6 excluded & & Fu et al., 2014 [4] \\
\hline 4 & 4 & LND & c. $532+1 G>A$ & Exon 7 excluded & & Fu et al., 2014 [4] \\
\hline 17 & 13 & HND & c. $584 A>C$ & p.Y195S & & $\begin{array}{l}\text { Laróvere et al., } 2004 \text { [19] } \\
\text { Laróvere et al., } 2007 \text { [25] } \\
\text { Jinnah et al., } 2010 \text { [22] }\end{array}$ \\
\hline 18 & 13 & HND & c. $584 \mathrm{~A}>\mathrm{C}$ & p.Y195S & & $\begin{array}{l}\text { Laróvere et al., } 2004 \text { [19] } \\
\text { Laróvere et al., } 2007 \text { [25] } \\
\text { Jinnah et al., } 2010 \text { [22] }\end{array}$ \\
\hline 19 & 13 & HND & c. $584 \mathrm{~A}>\mathrm{C}$ & p.Y195S & & $\begin{array}{l}\text { Laróvere et al., } 2004 \text { [19] } \\
\text { Laróvere et al., } 2007 \text { [25] } \\
\text { Jinnah et al., } 2010 \text { [22] }\end{array}$ \\
\hline 20 & 13 & HND & c. $584 \mathrm{~A}>\mathrm{C}$ & p.Y195S & & Fu et al., 2014 [4] \\
\hline 21 & 13 & HND & c. $584 A>C$ & p.Y195S & & Fu et al., 2014 [4] \\
\hline 22 & 13 & HND & c. $584 A>C$ & p.Y195S & New case & \\
\hline 23 & 13 & HND & c. $584 A>C$ & p.Y195S & New case & \\
\hline 24 & 13 & HND & c. $584 A>C$ & p.Y195S & New case & \\
\hline 25 & 13 & HND & c. $584 A>C$ & p.Y195S & New case & \\
\hline 26 & 13 & HND & c. $584 A>C$ & p.Y195S & New case & \\
\hline 27 & 14 & HND & c. $584 A>C$ & p.Y195S & $\begin{array}{l}\text { No knowledge of family history } \\
\text { (from mother) }\end{array}$ & Fu et al., 2014 [4] \\
\hline 5 & 5 & LND & c. $609+6 T>G$ & E8 excluded & & Fu et al., 2014 [4] \\
\hline 6 & 5 & LND & $c .609+6 T>G$ & E8 excluded & & Fu et al., 2014 [4] \\
\hline 7 & 6 & LND & Exons 4-6 deleted & 3 exons deleted & & Fu et al., 2014 [4] \\
\hline
\end{tabular}


compromise suggests an attenuated variant. An early diagnosis allows establishing treatment with allopurinol, thus avoiding the development of gouty manifestations and renal failure.

\section{Acknowledgements}

The authors gratefully acknowledge Dr. Patrick O’Neill for verifying the mutations in some patients. They also thank colleagues who referred cases.

\section{Funding}

The author(s) disclosed receipt of the following financial support for the research, authorship, and/or publication of this article: This study was supported by grants from Secretaría de Ciencia y Tecnología, Universidad Nacional de Córdoba and Consejo Nacional de Investigaciones Científicas y Técnicas (CONICET), Argentina.

\section{Declaration of Conflicting Interests}

The author(s) declared no potential conflicts of interest with respect to the research, authorship, and/or publication of this article.

\section{References}

1. Lesch M, Nyhan WL. A familial disorder of uric acid metabolism and central nervous system function. Am J Med. 1964;36:561-570. doi: 10.1016/0002-9343(64)90104-4

2. Jinnah HA, Friedman T. Lesch-Nyhan disease and its variants. In: Scriver CR, Beaudet AL, Sly WS, Valle D, eds. The Metabolic and Molecular Bases of Inherited Disease. 8th ed. New York: McGraw-Hill; 2001:2537-2570.

3. Madeo A, Di Rocco M, Brassier A, Bahi-Buisson N, De Lonlay P, Ceballos-Picot I. Clinical, biochemical and genetic characteristics of a cohort of 101 French and Italian patients with HPRT deficiency. Mol Genet Metab. 2019;127(2):147157. doi: 10.1016/j.ymgme.2019.06.001

4. Fu R, Ceballos-Picot I, Torres RJ, et al. Genotype-phenotype correlations in neurogenetics: Lesch-Nyhan disease as a model disorder. Brain. 2014;137(Pt 5):1282-1303. doi: 10.1093/brain/awt202

5. Becker MA, Yen RC, Itkin P, Goss SJ, Seegmiller JE, Bakay B. Regional localization of the gene for human phosphoribosylpyrophosphate synthetase on the $\mathrm{X}$ chromosome. Science. 1979;203(4384):1016-1019. doi: $10.1126 /$ science. 218284

6. Visser JE, Bär PR, Jinnah HA. Lesch-Nyhan disease and the basal ganglia. Brain Res Brain Res Rev. 2000;32(2-3):449475. doi: 10.1016/s0165-0173(99)00094-6
7. Ceballos-Picot I, Mockel L, Potier MC, et al. Hypoxanthineguanine phosphoribosyl transferase regulates early developmental programming of dopamine neurons: implications for Lesch-Nyhan disease pathogenesis. Hum Mol Genet. 2009;18(13):2317-2327. doi: 10.1093/hmg/ ddp164

8. Göttle M, Prudente CN, Fu R, et al. Loss of dopamine phenotype among midbrain neurons in Lesch-Nyhan disease. Ann Neurol. 2014;76(1):95-107. doi: 10.1002/ ana.24191

9. Harris JC. Lesch-Nyhan syndrome and its variants: examining the behavioral and neurocognitive phenotype. Curr Opin Psychiatry. 2018;31(2):96-102. doi: 10.1097/YCO.0000000000000388

10. Ceballos-Picot I, Le Dantec A, Brassier A, et al. New biomarkers for early diagnosis of Lesch-Nyhan disease revealed by metabolic analysis on a large cohort of patients. Orphanet J Rare Dis. 2015;10:7. doi: 10.1186/ s13023-014-0219-0

11. Torres RJ, Prior C, Garcia MG, Beltran LM, Puig JG. HPRT deficiency in Spain: what have we learned in the past 30 years (1984-2013)? Nucleosides Nucleotides Nucleic Acids. 2014;33(4-6):223-232. doi: 10.1080/15257770.2013.853784

12. de Gemmis P, Anesi L, Lorenzetto E, et al. Analysis of the HPRT1 gene in 35 Italian Lesch-Nyhan families: 45 patients and 77 potential female carriers. Mutat Res. 2010;692(12):1-5. doi: 10.1016/j.mrfmmm.2010.07.003

13. Cho JH, Choi JH, Heo SH, et al. Phenotypic and molecular spectrum of Korean patients with Lesch-Nyhan syndrome and attenuated clinical variants. Metab Brain Dis. 2019;34(5):1335-1340. doi: 10.1007/s11011-019-00441-0

14. Yamada Y, Wakamatsu N, Taniguchi A, Kaneko K, Fujimori $\mathrm{S}$. Hypoxanthine guanine phosphoribosyltransferase (HPRT) mutations in the Asian population. Nucleosides Nucleotides Nucleic Acids. 2011;30(12):1248-1255. doi: $10.1080 / 15257770.2011 .603714$

15. McCarthy GT, Green EM, Ogunbona O, et al. A population study of Lesch-Nyhan disease in the UK. Dev Med Child Neurol. 2011;53(1):34-39. doi: 10.1111/j.14698749.2010.03786.x

16. Crawhall JC, Henderson JF, Kelley WN. Diagnosis and treatment of the Lesch-Nyhan syndrome. Pediatr Res. 1972;6(5):504-513. doi: 10.1203/00006450-19720500000004

17. Jinnah HA. HPRT1 Disorders. [Updated 2020 Aug 6]. In: Adam MP, Ardinger HH, Pagon RA, et al., eds. GeneReviews ${ }^{\circledast}$. Seattle, WA: University of Washington, Seattle; 1993-2020. https://www.ncbi.nlm.nih.gov/books/ nbk1149/ 
18. Simmonds HA, Duley JA, Davies PM. Analysis of purines and pyrimidines in blood, urine and other physiological fluids. In: Hommes F, ed. Techniques in Diagnostic Human Biochemical Genetics: A Laboratory Manual. New York: Wiley-Liss; 1991:397-424.

19. Laróvere LE, Romero N, Fairbanks LD, et al. A novel missense mutation, c.584A > C (Y195S), in two unrelated Argentine patients with hypoxanthine-guanine phosphoribosyl-transferase deficiency, neurological variant. Mol Genet Metab. 2004;81(4):352-354. doi: 10.1016/j.ymgme.2004.01.013

20. Jinnah HA, De Gregorio L, Harris JC, Nyhan WL, O’Neill JP. The spectrum of inherited mutations causing HPRT deficiency: 75 new cases and a review of 196 previously reported cases. Mutat Res. 2000;463(3):309-326. doi: $10.1016 / \mathrm{s} 1383-5742(00) 00052-1$

21. Gibbs RA, Nguyen PN, Edwards A, Civitello AB, Caskey CT. Multiplex DNA deletion detection and exon sequencing of the hypoxanthine phosphoribosyltransferase gene in Lesch-Nyhan families. Genomics. 1990;7(2):235-244. doi: 10.1016/0888-7543(90)90545-6

22. Jinnah HA, Ceballos-Picot I, Torres RJ, et al. Attenuated variants of Lesch-Nyhan disease. Brain. 2010;133(Pt 3):671689. doi: 10.1093/brain/awq013
23. Sampat R, Fu R, Larovere LE, et al. Mechanisms for phenotypic variation in Lesch-Nyhan disease and its variants. Hum Genet. 2011;129(1):71-78. doi: 10.1007/ s00439-010-0901-9

24. Torres RJ, Puig JG. Hypoxanthine-guanine phosophoribosyltransferase (HPRT) deficiency: LeschNyhan syndrome. Orphanet J Rare Dis. 2007;2:48. doi: $10.1186 / 1750-1172-2-48$

25. Laróvere LE, O’Neill JP, Randall M, et al. Hypoxanthineguanine phosphoribosyltransferase deficiency: biochemical and molecular findings in six Argentine patients. Nucleosides Nucleotides Nucleic Acids. 2007;26(3):255-258. doi: 10.1080/15257770701257269

26. Sapag A, Frischling E, Laborde H. Hypoxanthine-guanine phosphoribosyltransferase deficiency in a patient with a Madrid II mutation. Joint Bone Spine. 2013;80(1):93-95. doi: 10.1016/j.jbspin.2012.06.020

27. Jinnah HA, Visser JE, Harris JC, et al. Delineation of the motor disorder of Lesch-Nyhan disease. Brain. 2006;129(Pt 5):1201-1217. doi: 10.1093/brain/awl056

28. Yamada Y, Nomura N, Yamada K, et al. Hypoxanthine guanine phosphoribosyltransferase (HPRT) deficiencies: HPRT1 mutations in new Japanese families and PRPP concentration. Nucleosides Nucleotides Nucleic Acids. 2014;33(4-6):218-222. doi: 10.1080/15257770.2013.865743 